\title{
Dysregulation of $\mathrm{Na}+/ \mathrm{K}+\mathrm{ATPase}$ by amyloid in APP+PSI transgenic mice Chad A Dickey, Marcia N Gordon, Donna M Wilcock, Donna L Herber, Melissa J Freeman and Dave Morgan*
}

Address: Alzheimer's Disease Research Laboratory, Department of Pharmacology, University of South Florida, Tampa, USA

Email: Chad A Dickey - cdickey@hsc.usf.edu; Marcia N Gordon - mgordon@hsc.usf.edu; Donna M Wilcock - dwilcock@hsc.usf.edu; Donna L Herber - dherber@hsc.usf.edu; Melissa J Freeman - mfreema1@hsc.usf.edu; Dave Morgan* - dmorgan@hsc.usf.edu

* Corresponding author

Published: 02 February 2005

BMC Neuroscience 2005, 6:7 doi:10.1 186/147/-2202-6-7
Received: 08 October 2004

Accepted: 02 February 2005

This article is available from: http://www.biomedcentral.com//47/-2202/6/7

(C) 2005 Dickey et al; licensee BioMed Central Ltd.

This is an Open Access article distributed under the terms of the Creative Commons Attribution License (http://creativecommons.org/licenses/by/2.0), which permits unrestricted use, distribution, and reproduction in any medium, provided the original work is properly cited.

\begin{abstract}
Background: The pathology of Alzheimer's disease (AD) is comprised of extracellular amyloid plaques, intracellular tau tangles, dystrophic neurites and neurodegeneration. The mechanisms by which these various pathological features arise are under intense investigation. Here, expanding upon pilot gene expression studies, we have further analyzed the relationship between $\mathrm{Na}+/ \mathrm{K}+$ ATPase and amyloid using APP+PSI transgenic mice, a model that develops amyloid plaques and memory deficits in the absence of tangle formation and neuronal or synaptic loss.

Results: We report that in addition to decreased mRNA expression, there was decreased overall $\mathrm{Na}+/ \mathrm{K}+$ ATPase enzyme activity in the amyloid-containing hippocampi of the APP+PSI mice (although not in the amyloid-free cerebellum). In addition, dual immunolabeling revealed an absence of $\mathrm{Na}+/ \mathrm{K}+$ ATPase staining in a zone surrounding congophilic plaques that was occupied by dystrophic neurites. We also demonstrate that cerebral $\mathrm{Na}+/ \mathrm{K}+$ ATPase activity can be directly inhibited by high concentrations of soluble $A \beta$.

Conclusions: The data suggest that the reductions in $\mathrm{Na}+/ \mathrm{K}+$ ATPase activity in Alzheimer tissue may not be purely secondary to neuronal loss, but may results from direct effects of amyloid on this enzyme. This disruption of ion homeostasis and osmotic balance may interfere with normal electrotonic properties of dendrites, blocking intraneuronal signal processing, and contribute to neuritic dystrophia. These results suggest that therapies aimed at enhancing $\mathrm{Na}+/ \mathrm{K}+\mathrm{ATPase}$ activity in AD may improve symptoms and/or delay disease progression.
\end{abstract}

\section{Background}

Alzheimer's disease (AD) has several well-characterized post-mortem pathological markers that include both gliosis and dystrophic neurites surrounding extracellular amyloid plaques. In addition, intracellular tangles of hyperphosphorylated tau and massive neurodegeneration are seen later in the disease process. Mutated forms of both amyloid precursor protein (APP) and presenilin 1 (PS1) lead to an increased rate of amyloid deposition and therefore an earlier onset of the dementia associated with $\mathrm{AD}$ [1]. Doubly transgenic mice expressing these human mutants of the APP [2] and PS1 [3] genes (APP+PS1 mice; [4] exhibit a large amount of amyloid deposition and gliosis without the formation of tangles or neuron loss, and 
yet they still develop anterograde amnesia as they age, similar to what is seen in the early stages of AD [5]. Memory deficits without the loss of neurons indicate that amyloid-associated disruption of some step in neural processing can result in memory deficits.

Previously we have described decreased expression of genes critical for learning and memory and impaired induction of several immediate early genes (IEGs) in aged, memory deficient APP+PS1 mice [6,7]. Increased neural activity during learning is argued to be a primary inducing stimulus for these IEGs [8]. One possible mechanism to describe this phenomenon would be that amyloid is diminishing the ability of neurons to facilitate sufficient electrical signaling to induce changes in synaptic plasticity essential for memory consolidation. Here we present evidence that in addition to decreased expression of $\mathrm{Na}+\mathrm{K}+$ ATPase mRNA as previously described $[6,7]$, the activity of this enzyme is significantly decreased in the APP+PS1 hippocampus but not in the amyloid-free cerebellum. Perhaps not surprisingly ouabain, an $\mathrm{Na}+\mathrm{K}+$ ATPase inhibitor, has been shown to impair memory consolidation $[9,10]$. We decided to investigate further the interactions of $A \beta$ and $\mathrm{Na}+/ \mathrm{K}+$ ATPase activity to understand better the potential role of this enzyme in $\mathrm{AD}$ and memory dysfunction.

\section{Results}

We used the APP+PS1 transgenic mouse model to better understand how the deposition of amyloid contributes to the consistent memory loss seen in these animals [11-14]. Specifically, we have found that $\mathrm{Na}+\mathrm{K}+$ ATPase, a protein critical for not only brain function, but survival, is adversely affected by the presence of amyloid and this interaction may be driving a major pathological event in the progression of amyloid-associated dementia.

In order to determine if our early observation regarding reduced mRNA for $\mathrm{Na}+/ \mathrm{K}+$ ATPase was functionally meaningful, we measured total and ouabain-sensitive ATPase activity in APP+PS1 brain homogenates compared to those from non-transgenic littermates using a standard colorimetric assay. Using ouabain as a selective inhibitor of $\mathrm{Na}+\mathrm{K}+$ ATPase, we demonstrated that the specific enzymatic activity was significantly reduced by $~ 25 \%$ in the hippocampi of aged, memory-deficient APP+PS1 mice compared with non-transgenic littermates (Figure 1B). The percent reduction in total ATPase activity was similar to that of specific $\mathrm{Na}+\mathrm{K}+$ ATPase activity, suggesting that inhibition of is selective for $\mathrm{Na}+/ \mathrm{K}+$ ATPase (Figure 1A \&1B). In addition, approximately $40 \%$ of all the ATP hydrolysis found in the homogenate was ouabain sensitive, confirming that this enzyme is likely the largest single site of ATP hydrolysis in brain. The specific activity values measured here were consistent with those reported 3 dec- ades ago by Stefanovic et al. [15], testifying to the robustness of the assay method. Upon analysis of the cerebellum of these mice, we found that the specific enzyme activity in APP+PS1 transgenics remained equivalent to that in non-transgenic littermates (Figure $1 \mathrm{~B}$ ); however the overall activity of $\mathrm{Na}+/ \mathrm{K}+$ ATPase in this region was only one fifth of that in the hippocampus (Figure 1A \&1B). Western blot analyses of cortical homogenates demonstrated a trend for reduced protein expression, a finding that would be expected based upon the mRNA analyses (Figure 1C).

Immunohistochemical staining for the $\mathrm{Na}+/ \mathrm{K}+$ ATPase $\alpha$ III subunit was performed using saggital sections from non-transgenic and APP+PS1 mice. Specific staining was observed throughout the forebrain. The specificity of the $\mathrm{Na}+\mathrm{K}+$ ATPase $\alpha$ subunit antibody used for immunochemistry was determined by pre-incubation of the antibody with purified $\mathrm{Na}+\mathrm{K}+$ ATPase protein, which dramatically reduced apparent immunostaining (Figure 2B) compared with normal staining (Figure 2A; amyloid plaques stained with Congo red dye appear red). Positive reaction product appeared to be localized to the periphery of cellular profiles in CA3 of the hippocampus (Figure 3A) and the insular cortex (Figure 3B), consistent with the enzyme's membrane-association. Throughout the brain, the white matter regions appeared to have less intense staining, than the neuropil, consistent with the larger numbers of ions crossing the membrane in post-synaptic potentials than action potentials (thus requiring more ionic pumping to maintain ionic equilibrium). Additionally, regions with high densities of neuronal somata also appeared to have less dense staining, reflecting the greater density of membrane area in dendritic than somatic regions of neuropil. Similar observations have been made using $[3 \mathrm{H}]$ ouabain to mark $\mathrm{Na}+\mathrm{K}+$ ATPase distribution in brain [16] Another striking observation from images of the hippocampus in non-transgenic mice (Figure 3C) demonstrate a decreased intensity of staining along the dentate granule cell projection pathways within the hilus and along the mossy fiber projections to CA3 (Figure 3A). This can also be observed at higher magnification in figure $3 \mathrm{~A}$, where there is reduced staining to the left of the somatic staining in the inner molecular layer. Although not commented upon, this too can be observed in micrographs of [3H] ouabain autoradiography [17].

Cortical staining (Figure 3D) revealed a fairly uniform pattern, with the exclusion of white matter. The difference in $\mathrm{Na}+/ \mathrm{K}+$ ATPase staining between non-transgenic and $\mathrm{APP}+\mathrm{PS} 1$ forebrain areas is the absence of staining where amyloid plaques are present in the APP+PS1 mice (Figure 3E \&3F). Subsequent Congo red staining of these amyloid plaques confirmed that the loss of $\mathrm{Na}+\mathrm{K}+$ ATPase staining was not only present in the center of the plaque, but also in a penumbral zone immediately surrounding the 
A

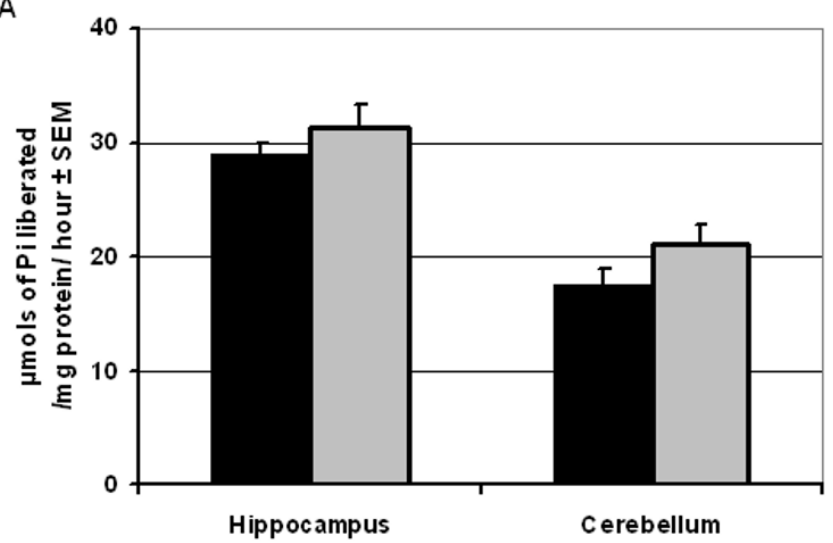

B

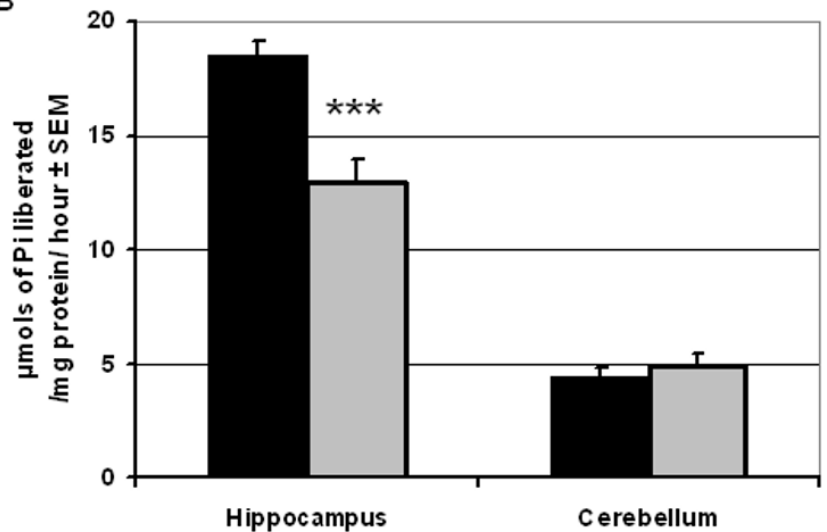

C

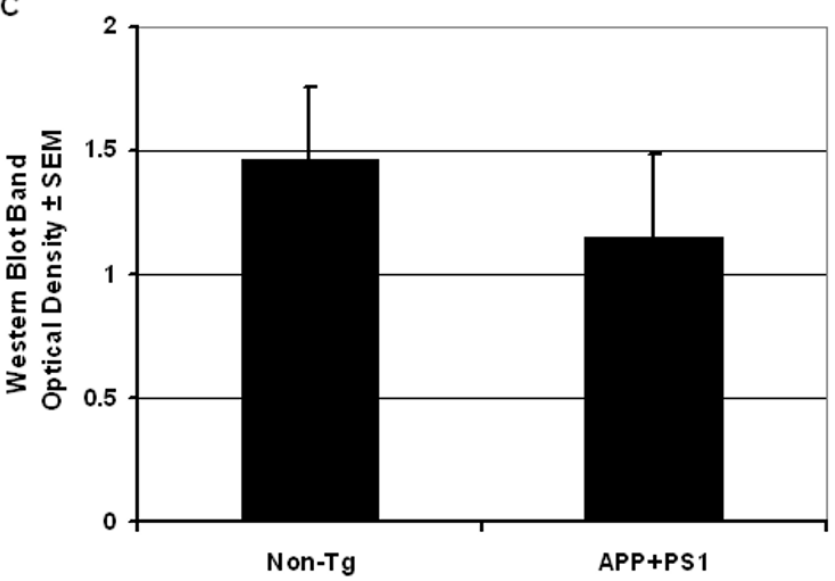

Figure I

Reduced activity and protein levels of the $\mathrm{Na}+\mathrm{K}+$ ATPase enzyme in APP+PSI mice. Activity of total (A) and ouabain-sensitive (B) ATPase was assayed colorimetrically in APP+PSI mice tissue $(n=8$, open bars) and non-transgenic littermate tissue $(n=8$, solid bars), presented here as $\mu$ mols of phosphate liberated by ATPase per $\mathrm{mg}$ of protein per hour. In the amyloid-containing hippocampus, there was a significant decrease in the specific activity of ouabain-sensitive ATPase in APP+PSI mice compared to non-transgenic mice, but there was no decrease in cerebellar $\mathrm{Na}+/ \mathrm{K}+\mathrm{ATPase}$ activity. Cerebellar activity was $20 \%$ of that seen in non-transgenic hippocampus. Panel $C$ shows the quantitation of the optical density of bands corresponding to the molecular weight of $\mathrm{Na}+/ \mathrm{K}+\mathrm{ATPase}$ using standard Western blot technique. This reveals a trend for decreased protein levels. *** indicates significant differences between APP+PSI mice and non-transgenic littermates $(p<0.001)$ when measured by oneway ANOVA. 

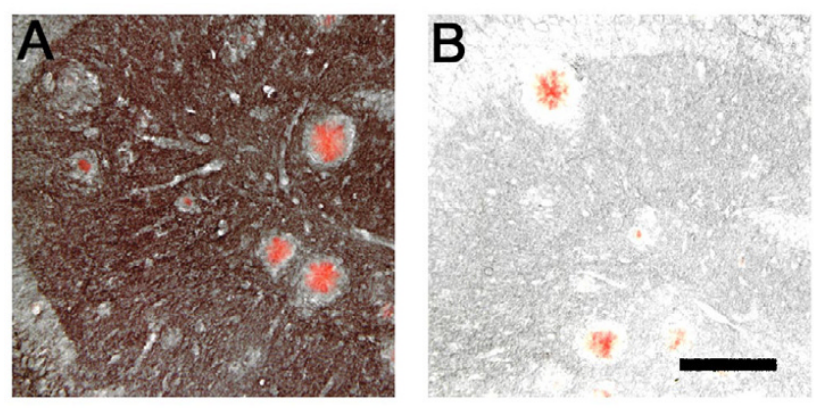

Figure 2

Verification of $\mathrm{Na}+/ \mathrm{K}+$ ATPase $\alpha$ lll antibody specificity by immunohistochemistry following pre-incubation with purified protein and Western blotting. Horizontal sections were immunostained for $\mathrm{Na}+/ \mathrm{K}+$ ATPase $\alpha$ lll with (Panel B) and without (Panel A) pre-incubation with $70 \mu$ units of purified enzyme followed by Congo red staining. The pre-incubation significantly decreased staining, confirming antibody specificity. Scale bar $=50 \mu \mathrm{m}$.

congophilic material, resulting in a "halo" (Figure 2A, 3G, $3 \mathrm{H}$ \&4A). Higher power magnification clearly demonstrated the lack of $\mathrm{Na}+\mathrm{K}+$ ATPase staining surrounding the congophilic plaques (Figure $4 \mathrm{~A}$ and $4 \mathrm{~B}$ ).

These findings led us to postulate that the osmotic imbalance brought on by an absence or inhibition of $\mathrm{Na}+\mathrm{K}+$ ATPase may contribute to the swelling associated with dystrophic neurites found in the vicinity of congophilic plaques in APP+PS1 mice and AD patients. We designed a dual immunostain utilizing immunohistochemical methods for $\mathrm{Na}+\mathrm{K}+$ ATPase and immunofluorescence methods for phosphorylated neurofilament, a dystrophic neurite marker we evaluated earlier [12]. Using this assay, we were able to demonstrate that the dystrophic neurites were almost exclusively present within the zone surrounding the congophilic plaque that lacked $\mathrm{Na}+\mathrm{K}+$ ATPase staining. This is represented in a triple staining overlay of the fluorescent neurites from figure $4 \mathrm{C}$ onto the bright field image of $\mathrm{Na}+\mathrm{K}+$ ATPase and Congo red staining from figure $4 \mathrm{~B}$ (Figure $4 \mathrm{D}$ ). The arrows in figure $4 \mathrm{C}$ demarcate where dystrophic neurites are present.

Finally, to determine whether amyloid could inactivate $\mathrm{Na}+\mathrm{K}+$ ATPase activity, we measured the activity of purified cerebral $\mathrm{Na}+/ \mathrm{K}+$ ATPase after exposure to various concentrations of $\mathrm{A} \beta$ 1-42 peptide in a DMSO+water suspension or a DMSO+neutralized $\mathrm{HCl}$ suspension. Figure 5 demonstrates that increasing concentrations of the DMSO+water A $\beta$ soluble preparation dose-dependently reduced $\mathrm{Na}+/ \mathrm{K}+$ ATPase activity, whereas the fibrillar $A \beta$ preparation suspended in DMSO+neutralized $\mathrm{HCl}$ did not demonstrate the same effect. There were significant reductions in $\mathrm{Na}+/ \mathrm{K}+$ ATPase activity at the lower concentrations of 112 and $225 \mu \mathrm{g} / \mathrm{ml}$ compared to vehicle, but maximal reductions were at the highest concentration of the DMSO+water A $\beta$ suspension $(450 \mu \mathrm{g} / \mathrm{ml})$.

\section{Discussion}

Over the past 6 years, our group has characterized various aspects of the APP+PS1 transgenic mice including their pathology, behavior, and gene expression. With age, these mice progressively develop more amyloid plaques surrounded by dystrophic neurites, activated microglia and astrocytes [12]. With increasing amyloid burden, aged animals consistently develop memory deficits in the radial arm water maze (RAWM; $[13,18,19]$, and, there is as yet no evidence for neuronal or synaptic loss. [6,20,21]. We have also demonstrated that several genes critical for synaptic plasticity and memory consolidation are downregulated in these mice exclusively in those brain regions which accumulate amyloid [6] and the induction of a subset of immediate-early genes is impaired when the transgenic mice are introduced to a novel environment [7].

Here, we show that $\mathrm{Na}+/ \mathrm{K}+$ ATPase has decreased enzyme activity in the amyloid-containing hippocampus of APP+PS1 transgenic mice. We have also demonstrated by immunohistology that $\mathrm{Na}+/ \mathrm{K}+$ ATPase protein expression is reduced in the immediate vicinity of congophilic plaques, a zone where dystrophic neurites are most prevalent, suggesting that disrupted ionic homeostasis may contribute to their formation. Additionally, high concentrations of $A \beta$ 1-42 directly inhibit the activity of $\mathrm{Na}+\mathrm{K}+$ ATPase. This suggests that in the area surrounding amyloid plaques, where the local $\mathrm{A} \beta$ concentration is likely high, $\mathrm{Na}+\mathrm{K}+$ ATPase activity may be locally inhibited.

From previous gene expression studies, we found that the mRNA for the $\mathrm{Na}+/ \mathrm{K}+$ ATPase $\alpha$ III subunit was consistently down-regulated $\sim 30 \%$ in the hippocampi of APP+PS1 mice compared to non-transgenic littermates and to the amyloid-free cerebella [6]. These reductions were also demonstrated in human Alzheimer's disease samples, consistent with data from previous investigations $[6,22]$. Using a sensitive colorimetric assay to measure activity of $\mathrm{Na}+/ \mathrm{K}+$ ATPase modified from Ellis et al. [23], we were able to demonstrate that in the APP+PS1 hippocampus, the specific activity of ouabain-sensitive ATPase was significantly reduced (figure 1B) while $\mathrm{Na}+$ / $\mathrm{K}+$ ATPase activity in the amyloid-free cerebellum remained unperturbed with respect to genotype. Cerebellar activity was substantially lower than that seen in the non-transgenic hippocampal tissue, perhaps indicative of the abundant white matter found in this region, where $\mathrm{Na}+\mathrm{K}+$ ATPase activity is low. These data demonstrate 


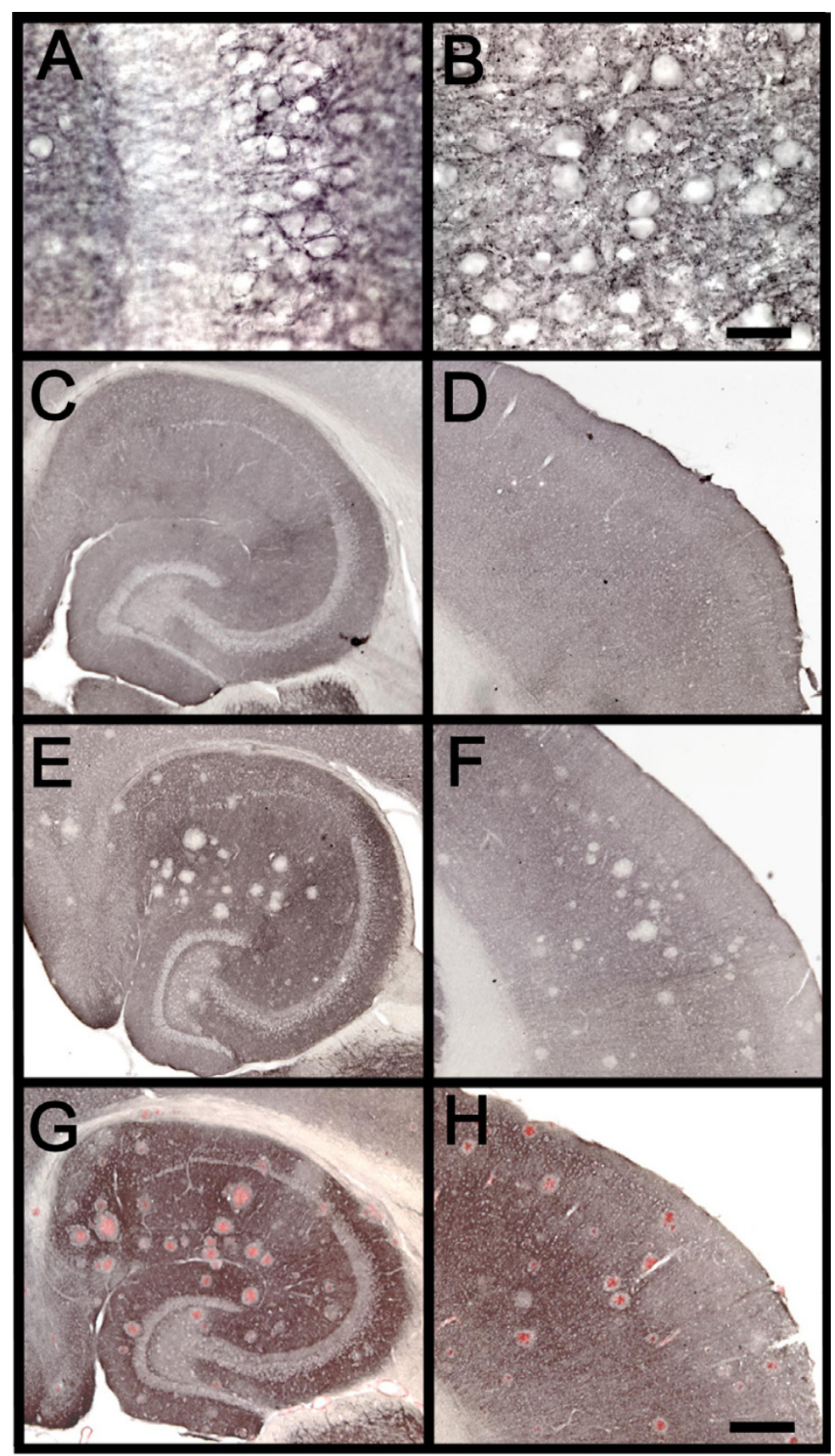

\section{Figure 3}

Hippocampal and cortical immunohistochemistry for $\mathrm{Na}+\mathrm{K}+$ ATPase in APP+PSI mice and non-transgenic littermates. Horizontal hippocampal and cortical sections were immunostained for $\mathrm{Na}+\mathrm{K}+\mathrm{ATPase} \alpha$ ll. The left panels depict hippocampus, while the right panels encompass the cerebral cortex. Panels A \& B: high power magnification (Scale bar $=8.33 \mu \mathrm{m})$ revealed membranelocalized staining for $\mathrm{Na}+/ \mathrm{K}+\mathrm{ATPase}$ in the insular cortex (Panel B) and CA3 of the hippocampus (Panel A) of non-transgenic mice. Panel C: hippocampal staining of non-transgenic mice showed a ubiquitous distribution of $\mathrm{Na}+/ \mathrm{K}+\mathrm{ATPase}$ throughout the neuropil, while less staining was apparent along the pyramidal layer of Ammon's horn, the hilus and the granular layer of the dentate gyrus. Panel D: cortical staining was also substantial with slight lightening in layers I and 2 . White matter in both structures remained unstained. A similar staining pattern was observed in the APP+PSI mice with the exception of focal non-stained areas in the gray matter, presumably where amyloid plaques are located (Panel E [hippocampus] \& $F$ [cortex]). Immunostaining followed by Congo red histochemistry confirmed that the $\mathrm{Na}+\mathrm{K}+\mathrm{ATPase}$ staining was absent not only immediately where amyloid was located, but also in a zone surrounding the plaque (Panels $\mathrm{G}$ [hippocampus] \& $\mathrm{H}$ [cortex]). Scale bar for panels $\mathrm{C}$ $\mathrm{H}=120 \mu \mathrm{m}$. 

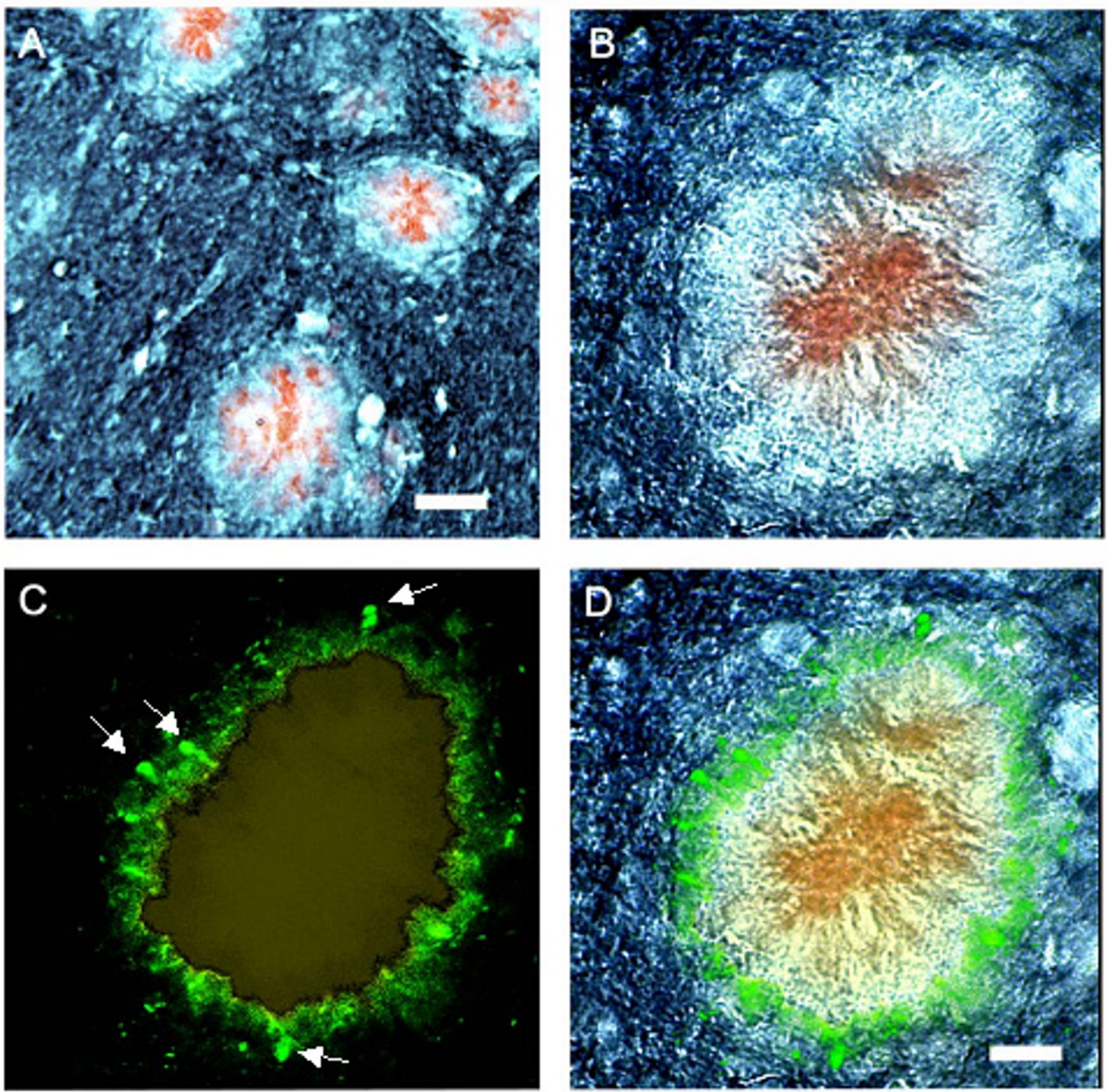

\section{Figure 4}

Dual Immunostaining of $\mathrm{Na}+/ \mathrm{K}+$ ATPase $\alpha$ lll and dystrophic neurites. Horizontal sections were immunostained for $\mathrm{Na}+/ \mathrm{K}+$ ATPase using DAB with nickel intensification followed by Congo red staining for $A \beta$ plaques. A discernable circumferential void in ATPase staining surrounding the plaque was observed (Panel A, scale bar $=50 \mu \mathrm{m}$; Panel B, scale bar $=16.67 \mu \mathrm{m}$ ). Immunofluorescent staining of dystrophic neurites using the anti-phosphorylated neurofilament antibody SMI-3 I 2 followed by Congo red staining demonstrate a close relationship between amyloid plaques and dystrophic neurites (Panel C; white arrows demarcate the neurites). Congo red yellow fluorescence was digitally suppressed to more clearly reveal the green-stained neurites (scale bar $=16.67 \mu \mathrm{m}$ ). Panel $\mathrm{D}$ is a digital overlay of the fluorescein-labeled dystrophic neurite image onto the bright field peroxidase-labeled $\mathrm{Na}+/ \mathrm{K}+$ ATPase + Congo red image which demonstrates that dystrophic neurites are present predominantly in the zone devoid of $\mathrm{Na}+/ \mathrm{K}+$ ATPase staining surrounding the congophilic plaques (scale bar $=16.67 \mu \mathrm{m})$. 


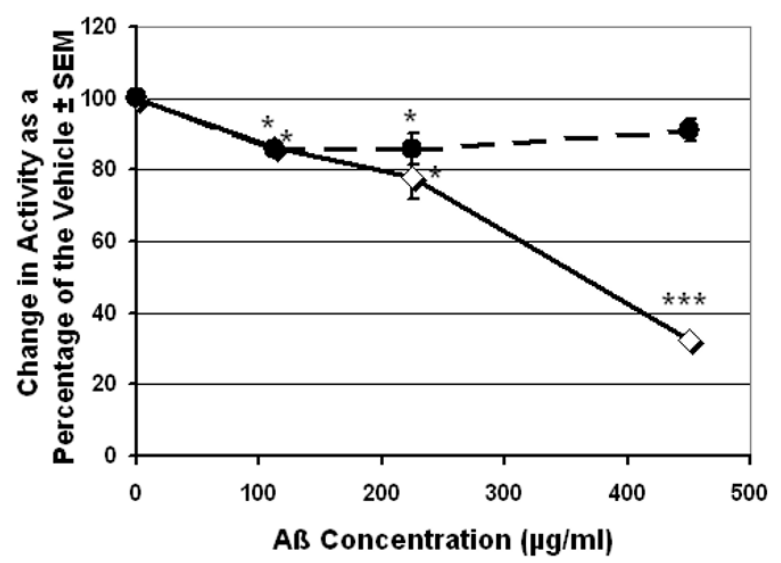

\section{Figure 5}

Amyloid-beta $1-42$ peptide inhibits $\mathrm{Na}+/ \mathrm{K}+$ ATPase activity. Purified cerebral $\mathrm{Na}+/ \mathrm{K}+\mathrm{ATPase}$ was pre-incubated with vehicle or $A \beta \mathrm{I}-42$, and enzyme activity percentages of the vehicle (20 $\mu \mathrm{mols} \mathrm{Pi} / \mathrm{mg}$ protein/hour) are presented (mean $\pm \mathrm{SEM}$ ). " $\diamond$ " indicates the values for the soluble (DMSO+water) A $\beta$ suspension. " $\bigcirc$ " indicates the values for the fibrillar (DMSO+neutralized $\mathrm{HCl}$ ) $\mathrm{A} \beta$ suspension. At the highest concentrations, the soluble preparation dramatically reduces $\mathrm{Na}+/ \mathrm{K}+$ ATPase activity compared to both vehicle and the fibrillar $A \beta$ preparation. * $(p<0.05)$ and $* * *(p<0.00 \mathrm{I})$ indicates significant differences between $A \beta$ and vehicle alone when measured by one-way ANOVA.

that the function of $\mathrm{Na}+/ \mathrm{K}+$ ATPase is perturbed in a brain region that contains high overall concentrations of $A \beta$.

Previous investigations have shown that $\mathrm{Na}+\mathrm{K}+$ ATPase protein levels are decreased in $\mathrm{AD}$ tissue but not in normal aged tissue [24,25], but it is difficult to dissociate the loss due to neuronal death from any loss caused directly by $\mathrm{A} \beta$ inhibition. This demonstration that reduced activity along with a trend for reduced protein levels can be determined in homogenates from animal models of amyloid deposition argues that at least some of this loss in AD brain is associated with direct actions of $A \beta$. In vitro data suggests that $\mathrm{Na}+\mathrm{K}+$ ATPase activity can be blocked directly by various $A \beta$ peptide fragments in cultured neurons [26] and that even the purified enzyme can be inhibited by high concentrations of $A \beta$ (Figure 5).

When we immunostained transgenic mouse tissue to visualize the distribution of $\mathrm{Na}+/ \mathrm{K}+$ ATPase alpha III subunits we found that in areas where congophilic plaque staining was apparent, $\mathrm{Na}+/ \mathrm{K}+$ ATPase staining was absent, and more specifically, there appeared to be no or little $\mathrm{Na}+\mathrm{K}+$ ATPase staining in a penumbral zone surrounding the plaques stained with Congo red (Figures $3 \mathrm{E}-\mathrm{H}$ and $4 \mathrm{~A}-\mathrm{B})$. While most immunostaining protocols detect voids at the sites where congophilic plaques are located, these areas appeared somewhat larger in the $\mathrm{Na}+$ / $\mathrm{K}+$ ATPase immunostained sections. This led us to speculate about that a reduction in the activity of this extremely important enzyme may have severe impacts on the functions of neurons in the vicinity of the deposits.

We knew from previous studies that dystrophic neurites could be visualized surrounding amyloid plaques in the $\mathrm{APP}+\mathrm{PS} 1$ mice. And we have demonstrated previously that proteins such as synaptophysin and APP are in fact increased in dystrophic neurites [12]. Therefore, we decided to stain sections for $\mathrm{Na}+/ \mathrm{K}+$ ATPase and dystrophic neurites, along with amyloid plaques using Congo red, to determine whether $\mathrm{Na}+\mathrm{K}+$ ATPase was absent from these neurites and in their immediate vicinity. We found empirically that staining the ATPase with a peroxidase label and the phosphorylated neurofilament with a fluorescein label to detect dystrophic neurites was the most effective way to see both markers on the same section along with the Congo red stained plaques. Imaging of these sections revealed that dystrophic neurites are in the circumferential area surrounding the congophilic amyloid plaques where $\mathrm{Na}+/ \mathrm{K}+$ ATPase staining is absent (Figure 4D).

One possible explanation for this putative relationship would be that $A \beta$ associated inhibition of $\mathrm{Na}+/ \mathrm{K}+$ ATPase activity would result in osmotic imbalance and cause the neurites to begin swelling. In addition to the loss of electronic properties and accompanying dysregulation of neuronal signaling, these changes might even feedback to influence gene expression. Indeed, Huang et al. demonstrated that cells exposed to ouabain have reduced $\mathrm{Na}+$ / $\mathrm{K}+$ ATPase $\alpha$ III subunit mRNA expression [27]. An alternative pathway may involve interactions of $A \beta$ with surface proteins, such as integrins $[28,29]$. and focal adhesion proteins [30] leading to activation of signal transduction cascades that mediate tyrosine phosphorylation [31]. Bozulic et al. reported that the tyrosine kinase, Lyn, can phosphorylate $\mathrm{Na}+\mathrm{K}+$ ATPase resulting in its removal from the membrane [32]. These findings suggest that either direct inhibition of $\mathrm{Na}+\mathrm{K}+$ ATPase by amyloid or its removal due to amyloid-mediated activation of a signaling cascade, could contribute to the formation of dystrophic neurites due to osmotic and/or ionic imbalances.

$\mathrm{A} \beta$ has been shown to bind various cell surface proteins $[26,33,34]$. and induce neuro-toxicity in vitro [35-37]. To determine the effect of $\mathrm{A} \beta \mathrm{1-42}$ on $\mathrm{Na}+/ \mathrm{K}+$ ATPase activity, we pre-incubated purified $\mathrm{Na}+\mathrm{K}+$ ATPase with $\mathrm{A} \beta$ 
then colorimetrically measured enzyme activity. Although both preparations of $A \beta$ did suppress activity at $112 \mu \mathrm{g} / \mathrm{ml}$ $(\sim 10 \mu \mathrm{M})$ and $225 \mu \mathrm{g} / \mathrm{ml}(\sim 50 \mu \mathrm{M})$, it was the highest concentration $(450 \mu \mathrm{g} / \mathrm{ml}$ or $\sim 100 \mu \mathrm{M})$ of the soluble $\mathrm{A} \beta$ suspension that precipitated the largest reduction in activity compared to vehicle, nearly rendering it completely inactive (Figure 5). The fibrillar $A \beta$ preparation did not exact the same precipitous decline in activity, demonstrating that it is not simply an artifact caused by high concentrations of a peptide that reduced activity. Further investigations will be required to determine which physicochemical form of $A \beta$ is causing the reduced activity. This suggests that the $A \beta$ can directly bind to the $\mathrm{Na}+\mathrm{K}+$ ATPase and decrease its activity. Mark et al. suggests that the 25-35 amino acid region of the $\mathrm{A} \beta$ peptide induces oxidative stress thereby impairing $\mathrm{Na}+\mathrm{K}+$ ATPase activity [26], and the findings presented herein are consistent with this earlier work.

\section{Conclusions}

These data indicate that $\mathrm{A} \beta$ deposition in transgenic mice is associated with reduced activity of $\mathrm{Na}+\mathrm{K}+$ ATPase. In vitro studies suggest that high concentrations of $A \beta$ can quickly inactivate the enzyme activity. One area in the brain that might harbor $A \beta$ concentrations sufficient to suppress the activity of $\mathrm{Na}+/ \mathrm{K}+$ ATPase would be the micro-domain near and immediately around the plaques. This is the area demonstrated to have reduced immunostaining for $\mathrm{Na}+\mathrm{K}+$ ATPase, while exhibiting increased phosphorylated neurofilament staining consistent with dystrophic neurites. These results lead to the possibility that one factor contributing to the formation of dystrophic neurites is loss of ionic homeostasis. Such changes might explain the "swollen" nature of these neuronal processes in the vicinity of plaques. It might also lead to sufficient disruption of electro-chemical properties as to disrupt normal information processing and lead to memory dysfunction. If these suggestions are correct, drugs targeted at activating $\mathrm{Na}+/ \mathrm{K}+$ ATPase and maintaining ionic balance in these neurons may benefit Alzheimer's patients by delaying the onset of neuritic dystrophia and memory dysfunction.

\section{Methods}

\section{Tissue preparation}

Mice were bred in our facility and genotyped using previously described methods [19] The working memory performance of the APP+PS1 mice used in these studies was impaired when compared to non-transgenic littermates as published previously [14]; untreated groups were studied here). For tissue collection, 17-18 month old mice were deeply anesthetized with pentobarbital $(100 \mathrm{mg} / \mathrm{kg})$ and perfused transcardially with phosphate buffered saline. Brains were removed and bisected into right and left hemispheres. The right hemisphere was immediately dissected into regions that were immediately frozen on dry ice, while the left hemisphere was post-fixed in $4 \%$ para-formaldehyde for 24 hours and subsequently processed through a cryo-protection schedule of 10, 20 and 30\% sucrose. Frozen brains were sectioned horizontally on a sliding microtome at $25 \mu \mathrm{m}$ and stored in Dulbecco's phosphate buffered saline plus azide at $4^{\circ} \mathrm{C}$.

\section{$\mathbf{N a}+/ \mathbf{K}+$ ATPase activity assay and amyloid preparation}

An assay to detect specific activity of $\mathrm{Na}+\mathrm{K}+$ ATPase by measuring the release of phosphate was developed using a variation of the method described by Ellis et al. [23]. Freshly frozen dissected hippocampi, cortex and cerebella (20-30 mg tissue weight) from APP+PS1 and non-transgenic littermates were homogenized using a rotor-stator homogenizer in $1 \mathrm{ml}$ of cold suspension buffer containing $85 \mathrm{mM}$ sodium chloride $(\mathrm{NaCl}), 20 \mathrm{mM}$ potassium chloride $(\mathrm{KCl}), 4 \mathrm{mM}$ magnesium chloride $(\mathrm{MgCl}), 0.2$ $\mathrm{mM}$ EGTA and $30 \mathrm{mM}$ histidine $\mathrm{pH}$ 7.2. Saponin was added to the samples to a final concentration of $20 \mu \mathrm{g} / \mathrm{ml}$. They were then incubated at $37^{\circ} \mathrm{C}$ for 15 minutes. Protein concentration was measured by Bradford assay and concentrations were adjusted to $10 \mathrm{mg} / \mathrm{ml}$.

In a 96-well plate, $60 \mu \mathrm{l}$ of ATP buffer containing $140 \mathrm{mM}$ $\mathrm{NaCl}, 20 \mathrm{mM} \mathrm{KCl}, 3 \mathrm{mM} \mathrm{MgCl}, 30 \mathrm{mM}$ histidine and 3 $\mathrm{mM}$ ATP were added to wells. Two sets of samples were included, one with ATP buffer only and the other with $100 \mu \mathrm{M}$ of the $\mathrm{Na}+/ \mathrm{K}+$ ATPase selective inhibitor ouabain added to the ATP buffer. Subsequently, $10 \mu \mathrm{l}$ of protein homogenates were added to the ATP buffer \pm ouabain, which were then mixed by pipetting and incubated at $37^{\circ} \mathrm{C}$ for 30 minutes. The reaction was stopped by adding $120 \mu \mathrm{l}$ of an acid molybdate solution consisting of $0.5 \mathrm{~g}$ ammonium molybdate (Sigma, St. Louis, MO) in $0.5 \mathrm{M}$ sulfuric acid. After mixing, $10 \mu \mathrm{l}$ of Fiske Subbarow Reducer (Sigma, St. Louis, MO) was added and wells were mixed again. The plate was allowed to incubate covered at room temperature for 10 minutes and then measured spectrophotometrically at $660 \mathrm{~nm}$. A standard curve of phosphoric acid dilutions was used to calculate the specific activity of the ouabain sensitive ATP hydrolysis and converted to $\mu$ mols of inorganic phosphate (Pi) liberated/ $\mathrm{mg}$ protein/ hour. All reactions were performed in triplicate, which were then averaged to produce the single value for the sample. Differences between APP+PS1 and nontransgenic mice were analyzed for significance using oneway ANOVA. A $\beta$ used for these studies was generated by resuspending $1 \mathrm{mg}$ of commercially available recombinant $\mathrm{A} \beta$ 1-42 peptide (rPeptide, Athens, GA) in $221 \mu \mathrm{l}$ of 1,1,1,3,3,3-Hexafluoro-2-propanol (HFIP, Sigma, St. Louis, MO) to generate $45 \mu \mathrm{g}$ A $\beta$ 1-42 films. These films were resuspended in $2 \mu \mathrm{l}$ of anhydrous DMSO, followed by agitation and subsequent addition of either $48 \mu \mathrm{l}$ of cold water followed by overnight incubation at $4{ }^{\circ} \mathrm{C}$ (for 
soluble $\mathrm{A} \beta$ preparation) or $10 \mathrm{mM} \mathrm{HCl}$ followed by overnight incubation at $37^{\circ} \mathrm{C}$ (for fibrillar $\mathrm{A} \beta$ preparation). The acid was neutralized the following day by the addition of $\mathrm{NaOH}$. These preparations yielded approximately $900 \mu \mathrm{g} / \mathrm{ml}$ suspensions of $\mathrm{A} \beta$.

For analysis of activity inhibition by both preparations of A $\beta$, purified $\mathrm{Na}+/ \mathrm{K}+$ ATPase (from brain; Sigma, St. Louis, $\mathrm{MO}$ ) was pre-incubated for 2 hours in a $37^{\circ} \mathrm{C}$ orbital shaker separately with $112.5,225$ and $450 \mu \mathrm{g} / \mathrm{ml}$ of either a DMSO+water A $\beta$ suspension or a DMSO+neutralized $\mathrm{HCl} A \beta$ suspension. Vehicle alone was also used for each preparation and sample values are indicated as a percentage of the "vehicle only" values. Activity was then measured using the same activity assay as above and significance was measured using one-way ANOVA comparing activity between vehicle treated and $A \beta$ treated.

\section{Western blot}

Brain homogenate from cortical tissue was equilibrated to $10 \mu \mathrm{g}$ of total protein. This homogenate, along with $1 \mu \mathrm{g}$ of purified cerebral $\mathrm{Na}+/ \mathrm{K}+$ ATPase, was diluted 1:1 with loading buffer containing 4\% SDS and 5\% $\beta$-mercaptoethanol, heated to $95^{\circ} \mathrm{C}$ for 5 minutes and loaded onto a $7.5 \%$ Tris-glycine gel which was electrophoresed at 100 $\mathrm{mV}$ for one hour in the presence of SDS. The protein was subsequently transferred onto an Immobilon membrane (Millipore, Billerica, MA) for one hour at $100 \mathrm{mV}$. The blot was rinsed with borate saline $+0.05 \%$ Tween-20 (BST) and blocked overnight at $4^{\circ} \mathrm{C}$ in $5 \%$ non-fat dry milk (NFDM). The following day, a 1:2000 dilution of rabbit anti-rat $\mathrm{Na}+/ \mathrm{K}+$ ATPase $\alpha$ III antibody (Upstate Biotech, Lake Placid, NY) in 0.5\% NFDM+BST was applied to the blot for 1 hour, followed by washing and a subsequent 1 hour incubation with a 1:5000 dilution of hrp-labeled anti-rabbit IgG (Sigma, St. Louis, MO) in $0.5 \%$ NFDM+BST. After washing, the blot was developed for chemiluminescence using a luminol substrate kit (Santa Cruz Biotech, Santa Cruz, CA). Band density was quantified using the SoftMax Pro program and one-way ANOVA was used to determine significance.

\section{Histology}

Immunohistochemical and immunofluorescence analyses for $\mathrm{Na}+/ \mathrm{K}+$ ATPase $\alpha$ III and phosphorylated neurofilament, respectively, were performed on the same $25 \mu \mathrm{m}$ free-floating hippocampal sections. Sections were treated 15 minutes with 10\% methanol, 3\% hydrogen peroxide and $80 \%$ phosphate buffered saline (PBS) to block endogenous peroxidase activity, and then washed 3 times with PBS. Sections were subsequently treated with sodium borohydride for 15 minutes to reduce background autofluorescence [38] followed by washing with PBS. Sections were then permeabilized for 30 minutes with $100 \mathrm{mM}$ lysine, $0.2 \%$ triton $\mathrm{x}-100,2 \%$ goat serum and $2 \%$ horse serum in PBS, and washed 3 times with PBS. Because one antibody was murine being used on mouse tissue, endogenous mouse IgG was first blocked with a 1:300 dilution of goat F ( $\left.\mathrm{ab}^{\prime}\right) 2$ anti-mouse IgG (overnight; Protos Immunoresearch, Burlingame, CA). Sections were washed the following day and co-incubated with a 1:5000 dilution of a rabbit anti-rat $\mathrm{Na}+\mathrm{K}+$ ATPase $\alpha$ III IgG (Upstate Biotech, Lake Placid, NY) and a 1:10,000 dilution of a mouse monoclonal IgG1 ascites pool specific for phosphorylated forms of neurofilament (SMI-312; Sternberger Monoclonals, Lutherville, MD) in $2 \%$ goat serum and $2 \%$ horse serum in PBS. The following day, sections were washed, and then co-incubated in both a 1:3000 dilution of anti-rabbit biotinylated secondary antibody (Vector Laboratories, Burlingame, CA) and a 1:100 dilution of anti-mouse fluorescein conjugated secondary antibody (Vector Labs, Burlingame, CA) for 2 hours. After washing, the tissue was incubated with Vectastain ${ }^{\circledast}$ Elite $^{\circledast}$ ABC kit (Vector Labs, Burlingame, CA). The tissue was then washed and stained with a diaminobenzidine: peroxide system plus nickel enhancement $\left(\mathrm{DAB} / \mathrm{Ni}^{2+}\right)$, followed by final washes. Compact amyloid plaques were visualized using Congo red staining after sections were slide mounted and dried [19]. Briefly, slides were incubated in alkaline alcoholic saturated sodium chloride (AASSC), followed by $0.2 \%$ Congo red in AASSC, then dehydrated and cover-slipped with xylene-free Vectamount (Vector Labs, Burlingame, CA). Other mounting media were tested, but only Vectamount was suitable for combined immunohistochemistry, immunofluorescence and Congo red staining. The extent of nonspecific binding was assessed in the absence of primary antibodies for all assays. Specificity of the $\mathrm{Na}+/ \mathrm{K}+$ ATPase antibody was confirmed by reduced staining following a 2 hour preincubation of the antibody with purified cerebral $\mathrm{Na}+\mathrm{K}+$ ATPase at a 1 antibody to 4 enzyme molecule ratio. Both immunostains were characterized individually before the co-incubation procedure was implemented.

\section{Authors' contributions}

$\mathrm{C} \mathrm{D}$ contributed to the design the study, developed the activity assay, generated the $\mathrm{A} \beta$ preparations, performed the histology and western blotting, and drafted the article. M G was responsible for maintenance of the animals used in the study, prepared the tissue for subsequent analysis, and assisted in the design. Both D W and D H participated in the histology and contributed to the coordination of the study. M B facilitated the investigations and assisted with histology. M F performed the genotyping of the mice. D M conceived of the study, and contributed to its design and coordination, along with helping to draft the manuscript. All authors read and approved the final manuscript. 


\section{Acknowledgements}

This work was supported by AGI5490 and AGI 8478 from NIH.

\section{References}

I. Selkoe DJ: Clearing the brain's amyloid cobwebs. Neuron 200I, 32:177-180.

2. Hsiao K, Chapman P, Nilsen S, Eckman C, Harigaya Y, Younkin S, Yang F, Cole G: Correlative memory deficits, Abeta elevation, and amyloid plaques in transgenic mice. Science 1996, 274:99-102.

3. Duff K, Eckman C, Zehr C, Yu X, Prada CM, Perez-tur J, Hutton M, Buee L, Harigaya Y, Yager D, Morgan D, Gordon MN, Holcomb L, Refolo L, Zenk B, Hardy J, Younkin S: Increased amyloidbeta42(43) in brains of mice expressing mutant presenilin I. Nature 1996, 383:710-713.

4. Holcomb L, Gordon MN, McGowan E, Yu X, Benkovic S, Jantzen P, Wright K, Saad I, Mueller R, Morgan D, Sanders S, Zehr C, O'Campo K, Hardy J, Prada CM, Eckman C, Younkin S, Hsiao K, Duff K: Accelerated Alzheimer-type phenotype in transgenic mice carrying both mutant amyloid precursor protein and presenilin I transgenes. Nat Med 1998, 4:97-100.

5. Morgan D: Learning and memory deficits in APP transgenic mouse models of amyloid deposition. Neurochem Res 2003, 28:1029-1034.

6. Dickey CA, Loring JF, Eastman PS, Montgomery JR, Gordon M, Morgan DG: Selectively reduced expression of synaptic plasticityrelated genes in APP+PSI transgenic mice. J Neurosci 2003, 23:5219-5226.

7. Dickey CA, Gordon MN, Mason JE, Wilson NJ, Diamond DM, Guzowski JF, Morgan D: Amyloid suppresses induction of genes critical for memory consolidation in APP + PSI transgenic mice. J Neurochem 2004, 88:434-442.

8. Dragunow M: A role for immediate-early transcription factors in learning and memory. Behav Genet 1996, 26:293-299.

9. Watts ME, Mark RF: Separate actions of ouabain and cycloheximide on memory. Brain Res 1971, 25:420-423.

10. Mark RF, Watts ME: Drug inhibition of memory formation in chickens. I. Long-term memory. Proc R Soc Lond B Biol Sci I97I, I 78:439-454.

II. Morgan D, Diamond DM, Gottschall PE, Ugen KE, Dickey C, Hardy J, Duff K, Jantzen P, DiCarlo G, Wilcock D, Connor K, Hatcher J, Hope C, Gordon M, Arendash GW: A beta peptide vaccination prevents memory loss in an animal model of Alzheimer's disease. Nature 2000, 408:982-985.

12. Gordon MN, Holcomb LA, Jantzen PT, DiCarlo G, Wilcock D, Boyett KW, Connor K, Melachrino J, O'Callaghan JP, Morgan D: Time course of the development of Alzheimer-like pathology in the doubly transgenic PSI+APP mouse. Exp Neurol 2002, I 73:183-195.

13. Arendash GW, King DL, Gordon MN, Morgan D, Hatcher JM, Hope CE, Diamond DM: Progressive, age-related behavioral impairments in transgenic mice carrying both mutant amyloid precursor protein and presenilin-I transgenes. Brain Res 200I, 891:42-53.

14. Austin LA, Arendash GW, Gordon G, Diamond DM, DiCarlo G, Dickey C, Ugen KE, Morgan D: Short-term A-beta vaccinations do not improve cognitive performance in cognitivelyimpaired APP+PSI mice. Behav Neurosci 2003.

15. Stefanovic V, Ebel A, Hermetet JC, Mandel P: Na+-K+-ATPase activity in brain regions of $\mathbf{C 5 7}$ and DBA mice. $J$ Neurochem 1974, 22: I|39-1 |4|.

16. Brines ML, Gulanski BI, Gilmore-Hebert M, Greene AL, Benz EJJ, Robbins RJ: Cytoarchitectural relationships between [3H]ouabain binding and mRNA for isoforms of the sodium pump catalytic subunit in rat brain. Brain Res Mol Brain Res 1991, 10:139-150.

17. Maki AA, Baskin DG, Stahl WL: $[3 \mathrm{H}]$-ouabain binding sites in rat brain: distribution and properties assessed by quantitative autoradiography. J Histochem Cytochem 1992, 40:771-779.

18. Holcomb LA, Gordon MN, Jantzen P, Hsiao K, Duff K, Morgan D: Behavioral changes in transgenic mice expressing both amyloid precursor protein and presenilin-I mutations: lack of association with amyloid deposits. Behav Genet 1999, 29: $177-185$.

19. Gordon MN, King DL, Diamond DM, Jantzen PT, Boyett KV, Hope CE, Hatcher JM, DiCarlo G, Gottschall WP, Morgan D, Arendash
GW: Correlation between cognitive deficits and Abeta deposits in transgenic APP+PSI mice. Neurobiol Aging 200I, 22:377-385.

20. Irizarry MC, Growdon W, Gomez-Isla T, Newell K, George JM, Clayton DF, Hyman BT: Nigral and cortical Lewy bodies and dystrophic nigral neurites in Parkinson's disease and cortical Lewy body disease contain alpha-synuclein immunoreactivity. J Neuropathol Exp Neurol 1998, 57:334-337.

21. Takeuchi A, Irizarry MC, Duff K, Saido TC, Hsiao Ashe K, Hasegawa M, Mann DM, Hyman BT, Iwatsubo T: Age-related amyloid beta deposition in transgenic mice overexpressing both Alzheimer mutant presenilin I and amyloid beta precursor protein Swedish mutant is not associated with global neuronal loss. Am J Pathol 2000, I 57:33 I-339.

22. Chauhan NB, Lee JM, Siegel G]: Na,K-ATPase mRNA levels and plaque load in Alzheimer's disease. I Mol Neurosci 1997, 9:151-166.

23. Ellis DZ, Nathanson JA, Sweadner KJ: Carbachol inhibits $\mathbf{N a ( + ) - ~}$ K(+)-ATPase activity in choroid plexus via stimulation of the NO/cGMP pathway. Am J Physiol Cell Physiol 2000, 279:CI685-Cl693.

24. Harik SI, Mitchell MJ, Kalaria RN: Ouabain binding in the human brain. Effects of Alzheimer's disease and aging. Arch Neurol 1989, 46:95 I-954.

25. Liguri G, Taddei N, Nassi P, Latorraca S, Nediani C, Sorbi S: Changes in $\mathrm{Na}+, \mathrm{K}(+)-A T P a s e, \mathrm{Ca2(+)}$-ATPase and some soluble enzymes related to energy metabolism in brains of patients with Alzheimer's disease. Neurosci Lett 1990, I I 2:338-342.

26. Mark RJ, Hensley K, Butterfield DA, Mattson MP: Amyloid betapeptide impairs ion-motive ATPase activities: evidence for a role in loss of neuronal $\mathrm{Ca} 2+$ homeostasis and cell death. J Neurosci 1995, I 5:6239-6249.

27. Huang L, Kometiani $P$, Xie Z: Differential regulation of $\mathbf{N a} / \mathbf{K}$ ATPase alpha-subunit isoform gene expressions in cardiac myocytes by ouabain and other hypertrophic stimuli. J Mol Cell Cardiol 1997, 29:3 157-3167.

28. Sabo S, Lambert MP, Kessey K, Wade W, Krafft G, Klein WL: Interaction of beta-amyloid peptides with integrins in a human nerve cell line. Neurosci Lett 1995, 184:25-28.

29. Goodwin JL, Kehrli MEJ, Uemura E: Integrin Mac- I and beta-amyloid in microglial release of nitric oxide. Brain Res 1997 , 768:279-286.

30. Williamson R, Scales T, Clark BR, Gibb G, Reynolds CH, Kellie S, Bird IN, Varndell IM, Sheppard PW, Everall I, Anderton BH: Rapid tyrosine phosphorylation of neuronal proteins including tau and focal adhesion kinase in response to amyloid-beta peptide exposure: involvement of Src family protein kinases. J Neurosci 2002, 22:10-20.

31. Grace EA, Busciglio J: Aberrant activation of focal adhesion proteins mediates fibrillar amyloid beta-induced neuronal dystrophy. J Neurosci 2003, 23:493-502.

32. Bozulic LD, Dean WL, Delamere NA: The influence of Lyn kinase on Na,K-ATPase in porcine lens epithelium. Am J Physiol Cell Physiol 2004, 286:C90-C96.

33. Dineley KT, Westerman M, Bui D, Bell K, Ashe KH, Sweatt JD: Betaamyloid activates the mitogen-activated protein kinase cascade via hippocampal alpha7 nicotinic acetylcholine receptors: In vitro and in vivo mechanisms related to Alzheimer's disease. J Neurosci 200 I, 2 I:4I25-4I33.

34. Verdier Y, Penke B: Binding Sites of Amyloid beta-Peptide in Cell Plasma Membrane and Implications for Alzheimer's Disease. Curr Protein Pept Sci 2004, 5: 19-3I.

35. Caughey B, Lansbury PT: Protofibrils, pores, fibrils, and neurodegeneration: separating the responsible protein aggregates from the innocent bystanders. Annu Rev Neurosci 2003, 26:267-298.

36. Stine WBJ, Dahlgren KN, Krafft GA, LaDu MJ: In vitro characterization of conditions for amyloid-beta peptide oligomerization and fibrillogenesis. J Biol Chem 2003, 278: I I6I 2-I I622.

37. Gong Y, Chang L, Viola KL, Lacor PN, Lambert MP, Finch CE, Krafft GA, Klein WL: Alzheimer's disease-affected brain: presence of oligomeric A beta ligands (ADDLs) suggests a molecular basis for reversible memory loss. Proc Natl Acad Sci USA 2003, 100:10417-10422. 
38. Clancy B, Cauller LJ: Reduction of background autofluorescence in brain sections following immersion in sodium borohydride. J Neurosci Methods 1998, 83:97-102.

Publish with Biomed Central and every scientist can read your work free of charge

"BioMed Central will be the most significant development for disseminating the results of biomedical research in our lifetime. " Sir Paul Nurse, Cancer Research UK

Your research papers will be:

- available free of charge to the entire biomedical community

- peer reviewed and published immediately upon acceptance

- cited in PubMed and archived on PubMed Central

- yours - you keep the copyright 